\title{
Research on the Innovation of Accounting Concept and Financial Accounting System under the Background of Knowledge Economy
}

\author{
Zhengzhang Li \\ West Yunnan University, Lincang, Yunnan, 677000
}

Keywords: Accounting concept; Enterprise accounting; Funds movement; Asset impairment

\begin{abstract}
Financial accounting is the most important and basic professional course in many courses of accounting major in higher vocational colleges, which contains many contents and is very hard so that many students feel it is difficult to study. Integrating the boring accounting concept into the teaching of accounting practice can not only help students to deepen their understanding of practical operation, but also stimulate their interest in learning professional courses of accounting, which leads students to apply the thinking mode of accounting developed step by step to their work in the future.
\end{abstract}

The accounting concept mentioned in this paper is a general term for accounting theory, concept, framework, and system because the accounting concept is changing quietly with the continuous development of the accounting cause in China. From the perspective of the current situation in China, there is a relatively unified understanding of the accounting concept, which is presented in the form of "accounting standards for enterprises". The accounting concept mentioned in this paper include: (1) The purpose of accounting is to provide the accounting information required for the decision; (2) The quality of accounting information has two standards which is relevance and reliability; (3) Financial accounting relies on four premises, that is, accounting subject, sustainable management, accounting period and monetary measurement; (4) Accounting elements are divided into six categories, namely, they are assets, liabilities, ownership interest, income, expenses, and profits; (5) Accounting information is mainly published in three statements which are balance sheet, income statement and cash flow statement; (6) Financial reports should follow six principles which refer to objectivity, timeliness, clarity, importance, consistency, cost and benefit; (7) Financial reports can reflect three aspects of capabilities of enterprises which are profitability, debt paying ability and operation ability [1]. The basic standards of Accounting Standards for Business Enterprises convey the above concepts, while the specific standards implement and explain these concepts.

According to the teaching status in recent years, about $90 \%$ of students majoring in accounting are girls who may have the advantage of studying accounting, but their thinking characteristics also hinder their in-depth understanding of the entire theoretical system of accounting. In the teaching practice, it is found that girls are more concerned about how to complete the specific processing of the transaction and are willing to calculate the data and write accounting entries, while boys are more interested in understanding the background knowledge of accounting treatment and the impacts of the final results, and are less interested in the tedious calculation and complicated accounting entries. For reversing the thinking bias of students in learning, guiding them to think deeply and stimulating their interest in learning at the same time, it is believed that if the complex accounting concepts are infiltrated into the specific accounting practice teaching according to different contents, students will experience the extensive and profound knowledge of accounting rather than find the theory boring. When the students truly understand the concept which supported the accounting treatment and develop the thinking mode of accounting gradually, they will be able to think and solve problems from a higher level and a broader perspective in their future work.

\section{The infiltration of capital movement of accounting object}

In the study of "accounting basis" course, a concept which is "Accounting object refers to capital 
movement or value movement" is known early, specifically, accounting object refers to the capital movement of the accounting entity in the daily operational activities or business activities. For manufacturing industry, it is presented as the funds investment, capital circulation and turnover, and capital exit, etc. The main task of financial accounting is to express the process of the flow of funds more accurately based on this concept. Therefore, many accounts are set to record and reflect the various forms of funds according to the law of capital movement in accounting. It is easier for students to understand the accounts and the complicated relationship between them in accounting if the complicated and basic accounting of manufacturing supply, production and sales process is described under this premise.

For example, if the enterprise purchases production materials, when the purchased materials do not arrive at the warehouse, but the procurement business has occurred, then the "in-bound materials" is set to record the fund expression form at present. When the purchased materials are checked and stored in the warehouse, in-bound materials are converted into the materials stored in the warehouse, and the account should record that "in-bound materials" decrease and "raw materials" increase. When various materials are consumed for production, the product is not yet formed, so the "production cost" account is set to record the capital in the form of product. Only when the production of the product is completed, the capital consumed by the completed product will be transferred out of the "production cost" account and into the "merchandise inventory " account. The relationship between the accounts of "construction projects" and "fixed assets", "raw materials" and "outsourced materials", "revolving materials" and "homemade semi-finished products", and the associations of "bank deposits", "R \& D expenditure" and "intangible assets" are similar to this situation. The accounting of economic business matters is complicated as it is based on the fundamental task of reflecting the capital movement.

\section{The connotation and extension of accounting concept}

Trade receivable is a very common term in financial accounting, however, it is easy for students to interpret it broadly as the various payments that enterprises should receive accounts receivable which is another term on financial accounting and is quite different from trade receivable in the connotation and extension. Accounts receivable include various receivables received by enterprises and institutions, such as interest receivable, dividend receivable, allowance receivable, other receivables, notes receivable as well as trade receivable, which is almost equal to the concept of debt. However, trade receivable only refers to the payment that the enterprise should receive from the purchasing unit or the receiving unit for selling goods or providing services. In addition, there are several concepts which are easy to be confused. For example, notes receivable only refer to commercial bills received by enterprises for the sale of goods or provision of services while students often mistake them for all bills received, including checks, bank drafts, bank checks and commercial bills. The notes in accounting contain the above four, but notes receivable only refers to the commercial bills among them. This question is enough to confuse students who are new to accounting with little or no practical experience in accounting. Similar concepts and terms are too numerous to mention in financial accounting. Therefore, teachers should teach students to understand and learn to distinguish accounting concepts at first because there will be no proper use if the concepts are not clear.

\section{Measurement of asset impairment and loss}

The measurement of asset impairment and loss indicates not only the definition of "assets" in accounting, but also the relevance and reliability requirements of qualitative standards of accounting information. However, in the operation of accounting practice, it is more difficult to measure than other accounting elements. The reform of measurement in asset impairment and loss can be regarded as a wonderful chapter in the modern accounting history of China. It is interesting and informative to introduce its evolution process to students and lead them to understand the competition between "Tao" and "Demon". 
Bad-debt provision of accounting in our country has a long history, however, the ministry of finance in our country didn't make a clear regulation in the "Enterprise Accounting System" (finance and accounting) [2000] No. 25) until 2000 that 8 categories of capital such as accounts receivables provision for impairment is prepared and assets impairment loss is confirmed, which is considered to be significant progress in integrating with the international accounting practices. However, the situation next is definitely a "system" out of the planner's expectation. In the subsequent financial reports of some listed enterprises, this system, which is regarded as a sign of conformity, changes things completely as a sentence in the accounting system of enterprises, that is, "For the asset loss that has been confirmed and resold, if it is recovered later, the provision for asset impairment that has been accrued shall be adjusted accordingly"[2]. In this context, the ministry of finance issued the Accounting Standards for Enterprises (Decree No.33 the Ministry of Finance of the People's Republic of China) which redefined the problem of asset impairment on February 15, 2006. Receivables and inventories are retained in the original treatment principle, and trading financial assets are measured by fair value. Fixed assets and intangible assets stipulate that "once the impairment loss of assets is confirmed, it shall not be reversed during the later accounting period" clearly [3].

\section{The relationship between reform of tax law and financial accounting}

There is a close association between "finance" and "tax". The enterprise's tax declaration and the tax inspection of the tax bureau are both related to the financial department closely. Therefore, there are many contents related to the management of various taxes and fees in the course of financial accounting. For 18 tax forms conducted in our country, the content has been very complex. Although the students do not learn all the content in the financial accounting section, the relationship between "tax" and "wealth" is unable to be ignored. In addition to explaining the accounting treatment of common taxes, teachers will interweave tax regulations and tax law changes into teaching, which will not only enhance the understanding of accounting knowledge, but also help to improve students' learning interest and understanding level.

The value added tax experiences many changes quite recently in our country. In the Provisional Regulations of the People's Republic of China on value-added tax (Decree No. 134 the State Council [1993]) issued in 1993, the production Value Added Tax is conducted and the value-added tax paid by an enterprise for the purchase of machinery and equipment for production is not allowed to be deducted. For supporting the equipment renewal, technological transformation and industrial restructuring from the perspective of tax policy, the state administration of taxation has pointed out in the Regulations on the Expansion of the Scope of VAT Deduction in Northeast China (finance and tax [2004] No. 156): The policy of value-added tax deduction for newly added fixed assets was piloted in old industrial foundation in northeast China since July 1, 2004. After four and a half years of pilot project, the Provisional Regulations of the People's Republic of China on value-added tax (Decree No. 538 the State Council) issued on 5 November 2008 stipulate that since January 1, 2009, the value added tax reform has been carried out throughout the country, and the value-added tax has been changed from the production value-added tax to the general consumption value-added tax internationally which has reduced the tax burden of enterprise investment in equipment greatly. On November 16, 2011, the Pilot Scheme for Replacing Business Tax with Value-added Tax (finance and tax [2011] No. 110) jointly issued by the ministry of finance and the state administration of taxation indicated that on January 1, 2012, China began to promote the "replacing business tax with value added tax" in several batches, provinces, and other industries which is to replace business tax with value-added tax in transport and modern service industries in Beijing, Tianjin, Shanghai and other cities and regions. The change avoids double taxation as well as achieves tax reduction. In the process of teaching, if the teacher introduces the current accounting treatment of value-added tax along with the background, purpose, influence and changes of tax reform in the accounting treatment to the students, the students will have a broader perspective and a deeper understanding of the problems. 


\section{Acknowledgment}

Funding information: Research of the applied university major assessment for the Yunnan Higher Education Tearchers' Education League”, A Special Program for the Scientific Teachers Education Planning of Yunnan Province. GJZ1616

\section{References}

[1] $\mathrm{Xu}$ Jialin. On the theoretical study of accounting science under the guidance of accounting thinking (part ii) [J]. Communication of Finance and Accounting, 2011, (4): 11.

[2] The ministry of finance. Enterprise accounting system [M]. Beijing: China industry and commerce press, 2001:36.

[3] China accounting Network College. Accounting standards and related systems for new enterprises [M]. Beijing: The Oriental Press, 2006:405. 